\title{
Asking (Different) Responsibility Questions: Responsibility and Non- Resposibility in Criminal Law
}

\author{
ARLIE LOUGHNAN*
}

\section{Introduction}

This article begins with an observation: the legal scholarly analysis of criminal responsibility is typically assumed to encompass non-responsibility; that is, studying responsibility is taken to entail the study of non-responsibility. This state of affairs reflects the profound influence of the legal-philosophical scholarly tradition on the study of criminal responsibility. ${ }^{1}$ In this tradition, criminal responsibility tends to be approached as an abstract matter, with the enquiry framed in terms of rules about accountability that are indexed to moral norms, that is, to responsibility in general. ${ }^{2}$ This moral-evaluative enquiry is singular or unified - the question implicitly guiding this scholarship is something like 'who is responsible under criminal law?', or more accurately, 'who should be responsible

Faculty of Law, University of Sydney. I would like to thank Sabine Selchow, Kevin Walton, and Jeremy Gans and Lael Weis and the members of the Melbourne Legal Theory Workshop, University of Melbourne, for comments on an earlier version of this piece. Thanks also to Tatjana Hörnle for her encouragement, and to Louisa Vaupel for assistance in preparing the piece for publication. This research is supported by Australian Research Council Grant No. DE130100418, Responsibility in Criminal Law.

1 For critical discussion of the nature and effects of this influence, see Lacey, Institutionalising Responsibility: Implications for Jurisprudence 4(1) Jurisprudence (2013) 1-19; see also Loughnan, Historicizing Criminal Responsibility, in The New Philosophy of Criminal Law, eds. Flanders and Hoskins (Rowman and Littlefield 2016) pp. 133-151.

2 See e.g. Duff, Answering for Crime: Responsibility and Liability in the Criminal Law (Hart 2007); Gardner, The Mark of Responsibility, 23(2) Oxford Journal of Legal Studies (2003) pp. 157-171; Hart, Punishment and Responsibility: Essays in the Philosophy of Law, $2^{\text {nd }}$ ed. (Oxford University Press 2008); Tadros, Criminal Responsibility (Oxford University Press 2005). 
under criminal law?'. It is this question that generates a focus on the minimum conditions or capacities (moral, cognitive and volitional) an individual must have to be held responsible via criminal processes. ${ }^{3}$ In turn this produces a picture of responsibility and non-responsibility as different sides of the same coin, or, put another way, as alternative outcomes of the same moral-evaluative enquiry of calling individuals to account for their criminal conduct - in effect, as responsibility and a-responsibility.

Despite the richness of the legal-philosophical scholarly tradition, it tends to obscure significant dimensions of criminal responsibility. As a number of critical criminal responsibility scholars argue, criminal responsibility must be understood as a set of blaming practices that takes place in a (criminal) institutional context. ${ }^{4}$ On this approach, criminal responsibility is not a 'thin' or abstract product of certain rules or moral norms, but a social practice or a 'thick' legal 'thing', the product of a network of laws, processes, institutions and actors. ${ }^{5}$ This approach generates a different responsibility question - rather than 'who is responsible under criminal law?', the question becomes 'in what ways are individuals held responsible under criminal law?' - and this opens the way for multiple responses, or responses which vary from one part of the law to the other (and over time). As Nicola Lacey argues, this sort of approach involves asking not just what criminal responsibility 'is', but what it is 'for' - an enquiry that exposes its centrality to criminal law as a system of regulation. ${ }^{6}$ Approaching criminal responsibility this way extends the scholarly lens beyond conceptions of criminal responsibility (the 'nature' of criminal responsibility), to include responsibility ascription practices and the wider processes (such as evidence and proof) relating to evaluation and adjudication of individuals under criminal law.

On this approach to the study of criminal responsibility, it becomes clear that the operative assumption that responsibility and non-responsibility are alternative outcomes of the same kind of abstract moral-evaluative inquiry presents a rather slanted picture. A close assessment of criminal responsibility practices reveals that, in broad terms, responsibility and non-responsibility look different. By examining four dimensions of these practices - the bases for ascription of criminal responsibility and non-responsibility, attendant rules of evidence and procedure, the temporal logics of responsibility and non-responsibility, and what I call the effects of ascriptions of responsibility and non-re-

3 Lacey, Responsibility and Modernity in Criminal Law, 9(3) Journal of Political Philosophy (2001) pp. 249-276, at 255.

4 See e.g. Farmer, The Making of the Modern Criminal Law: Criminalization and the Civil Order (Oxford University Press 2016); Lacey, In Search of Criminal Responsibility: Ideas, Interests and Institutions (Oxford University Press 2016).

5 For accounts that adopt this 'thick' approach, see Cane, Responsibility in Law and Morality (Hart Publishing 2002); Veitch, Law and Irresponsibility: On the legitimation of Human Suffering (Routledge 2007).

$6 \quad$ See Lacey 2016, p. 2. 
sponsibility - it is possible to expose what I suggest are meaningful differences between these practices in criminal law. These differences reveal that the relationship between responsibility and non-responsibility is not as straightforward as typically assumed, as non-responsibility does not reduce to a-responsibility. Guided by the question 'how do criminal responsibility and non-responsibility practices compare?', this article sets out the differences between responsibility and non-responsibility practices, and explores their significance for our understanding of criminal responsibility.

In developing this sketch, I bring together disparate insights from various parts of criminal law scholarship and apply them to the study of responsibility practices. While there is a general understanding that the breakdown of the criminal law into components indicates that different parts do different things, ${ }^{7}$ and a growing awareness of the significance of institutional and other aspects of criminal responsibility practices, ${ }^{8}$ the implications of this for our understanding of the relationship between responsibility and non-responsibility practices have not yet been considered. In considering these implications, this article seeks to contribute to the relatively new but vibrant critical scholarship on criminal responsibility, developed by a number of scholars working within socio-historical and social theory disciplinary traditions. These scholars have shown that responsibility practices are marked by complexity and variation, and that responsibility in criminal law is intimately connected to larger issues of legal and social order. ${ }^{9}$ Inspired by this body of work, this article unpacks the relationship between responsibility practices and non-responsibility practices. This exploration opens up another line of inquiry in criminal responsibility scholarship, which may function as a corrective to existing scholarly accounts of criminal responsibility, and, in turn, contribute to the development and vitality of the scholarly field.

For the purposes of comparison with responsibility practices, throughout this article, I draw on the law of insanity (sometimes known as mental incapacity or mental incompetence). Insanity (alongside infancy or non-age) is widely recognised as the pre-eminent instance of non-responsibility in criminal law. As the Law Commission for England and Wales states, the 'true rationale' for the insanity defence is to deny criminal responsibility (not merely to deny mens rea). ${ }^{10}$ Thus, while insanity is typically labelled a 'defence' (language which, for convenience, I carry over into this article), insanity goes to criminal responsibility, rather than merely to criminal liability. As Antony Duff writes, insanity

7 See e.g. Norrie, Crime, Reason and History: A Critical Introduction to Criminal Law (Butterworths 2001); Robinson, Structure and Function in Criminal Law (Clarendon Press 1997).

$8 \quad$ See e.g. Duff et al., The Trial on Trial series vols. 1, 2, and 3 (Oxford University Press 2004, 2006, 2007).

$9 \quad$ See e.g. Farmer 2016; Lacey 2016.

10 See Law Commission for England and Wales, Insanity and Automatism: A Scoping Paper, July 2012, para. 2.73 . 
concerns an individual's 'capacity both to respond to reasons and then to answer [for him or herself].' ${ }^{11}$ In normative terms, individuals raising insanity are claiming to be exempt from, or beyond the reach of, the criminal law, understood as a system of moral-legal condemnation and sanction. While, elsewhere, I have cautioned against an overly strict separation of those criminal law doctrines classed as exemptions and those classed as excuses (where each concerns mental incapacity), ${ }^{12}$ here, I confine myself to a central case of non-responsibility.

In advance of the discussion of particular aspects of the insanity defence provided in the body of this article, a brief overview of it is appropriate. In the common law tradition, insanity is a general defence available across the board of criminal offences (although as a matter of practice, it tends to be raised only in relation to serious criminal charges ${ }^{13}$ ). As is well known, while the insanity defence is now buttressed by statutory rules, such as those concerning expert evidence, the test for insanity continues to be governed by the common law. In England and Wales, the test for insanity is provided by the M'Naghten Rules, formulated in response to the trial of Daniel M'Naghten, in 1843. ${ }^{14}$ The M'Naghten Rules comprise three limbs: they require that an individual have a 'defect of reason', resulting from a 'disease of the mind', and having the effect that the individual does not know the 'nature and quality' of his or her act, or that it was wrong. ${ }^{15}$ As the language of these three limbs suggests, the insanity defence is premised on an individual's mental incapacity, arising from mental disorder or disease. ${ }^{16}$ M'Naghten insanity is framed by distinctive rules of evidence and proof, such as that the defence must be left to the jury. ${ }^{17}$ Where the defence is successful, it results in what is called the special verdict 'not guilty by reason of insanity'. By contradistinction with an ordinary acquittal, the special verdict gives courts particular disposal powers (such as the power to detain an individual who is considered to be dangerous).

This article consists of four parts, each of which sets out one dimension of my analysis of the differences between responsibility and non-responsibility practices - the bases for the ascriptions of criminal responsibility and non-responsibility, evidence and proof, the temporal logics of responsibility and non-responsibility, and the effects of ascriptions of responsibility and non-responsibility. In each part, I draw on aspects of the law of

11 See Duff 2007 p. 41; see also Duff, Trials and Punishments (Cambridge University Press 1986).

12 See Loughnan, Manifest Madness: Mental Incapacity in Criminal Law (Oxford University Press, 2012), ch. 2.

13 See Mackay et al., Yet More Facts about the Insanity Defence, [2006] Criminal Law Review pp. 399-411.

$14 \quad$ M'Naghten's Case (1843) $10 \mathrm{Cl} \&$ Fin 200; see for discussion Loughnan, M'Naughten's Case, in Landmark Cases in Criminal Law, eds. Mares et al. (Hart Publishing, 2016) (forthcoming).

15 See M'Naghten's Case; see also Bratty v Attorney-General for Northern Ireland [1963] AC 386.

16 See further Mackay, Mental Condition Defences in Criminal Law (Clarendon Press 1995), ch. 2.

$17 \quad$ M'Naghten's Case; $R$ v Matheson [1958] 1 WLR 474 p. 480. 
insanity, as it applies in England and Wales, to illustrate the points being made about non-responsibility. My analysis exposes meaningful differences between responsibility and non-responsibility practices in criminal law, indicating that the relationship between the two is not as straightforward as typically assumed. In the conclusion, I briefly outline some of the implications of my analysis for the study of criminal responsibility.

\section{Bases of Ascriptions of Criminal Responsibility and Non-Responsi- bility}

The first dimension of my analysis of responsibility and non-responsibility practices concerns the bases of ascriptions of responsibility and non-responsibility. Here, ascription refers to the practice of assigning responsibility to someone or something. While ascription practices vary across the criminal law terrain - and my analysis should not be taken to imply any overarching neatness - in broad terms, there are differences in the bases of positive and negative ascriptions of responsibility. I suggest that the paradigm case of ascriptions of responsibility reflects what Lacey has called the "primarily capacity-based and heavily psychologised notion of mens rea' that marks 'the core of the late modern general part of the criminal law', ${ }^{18}$ while ascriptions of non-responsibility reflect older, character-like bases for exemption.

In the criminal law of the current era, the classic exemplar of the ascription of criminal responsibility is capacity, with its hallmarks of individual agency, choice and autonomy. Under 'the principle of responsibility as founded primarily in cognitive and volitional human capacities', criminal fault is subjective - it depends on what the accused himself or herself knew, believed or intended at the time of the conduct. ${ }^{19}$ Subjectivism has had a profound effect on the criminal law. The adoption of subjectivism meant that the general principles of criminal responsibility cohered around a particular, modern ascription of responsibility: that 'harmful wrongs or wrongful harms consist centrally in culpable con$d u c t{ }^{2}{ }^{20}$ Subjective mental states of intention and recklessness are regarded as axiomatic of criminal fault and are associated with the most serious offences in the criminal calendar. This is significant because, in its modern form, subjective fault is regarded as a means of respecting freedom of action and treating individuals as moral agents. ${ }^{21}$ Subjectivism has also influenced scholarly thinking about the criminal law - it has been labelled the 'most important intellectual influence' on modern criminal law scholars following the positiv-

See Lacey 2001 p. 266.

See Lacey 2013 p. 6.

See Farmer 2016 p. 164 (emphasis added).

See, e.g., Ashworth and Horder, Principles of Criminal Law $7^{\text {th }}$ ed. (Oxford University Press 2013). 
ist tradition of Jeremy Bentham. ${ }^{22}$ Orientation around a central case of capacity-based responsibility ensures the criminal law fits with a liberal political social structure that is concerned with individual autonomy, freedom, and privacy. ${ }^{23}$

Although representing the paradigm case, capacity-based ascriptions of criminal responsibility do not cover the field. Responsibility ascription practices are marked by variability and nuance across the terrain of criminal law. The most developed assessment of this issue is offered by Lacey who proposes a two-fold account (conceptual and historical) of dynamism in criminal responsibility ascription practices. ${ }^{24}$ In the conceptual strand of her analysis, Lacey argues that 'multiple and philosophically variegated' conceptions of responsibility are operating in the criminal law at any one time. ${ }^{25}$ For Lacey, there are three main concepts or principles of responsibility attribution operative across criminal law. These are: capacity (which stands for concern with agency, choice and individual autonomy), outcome (which concerns the social harms produced by crime), and character (which entails an 'evaluation or estimation of the quality of the defendant's (manifested or assumed) disposition as distinct from his or her conduct'). ${ }^{26}$ In her most recent work on this topic, Lacey includes risk as a fourth 'pattern of responsibility-attribution'. Risk features in practices of preventive criminalisation that are particularly prominent in the current era. ${ }^{27}$ In the historical strand of her analysis, Lacey makes the case for significant change over time in criminal responsibility ascription practices, with, in broad terms, ideas of responsibility 'as founded in character' gradually giving way to 'conceptions of responsibility as founded in capacity' over the last two centuries. ${ }^{28}$

In relation to positive ascriptions of responsibility, a significant change is currently underway, as pre-modern, character-based conceptions of (positive ascriptions of) criminal responsibility are enjoying a resurgence in the current era. Lacey sees this trend as

22 Horder, Criminal Law in Oxford Handbook of Legal Studies eds. Cane and Tushnet (Oxford University Press 2003) pp. 226-249, at 230. On Bentham generally, see Postema, Bentham and the Common Law Tradition (Clarendon Press, 1986) and Lobban, The Common Law and English Jurisprudence 1760-1850 (Clarendon Press 1991) ch. 5.

23 See for discussion Harel, The Triadic Relational Structure of Responsibility: A Defence in Crime, Punishment and Responsibility: The Jurisprudence of Antony Duff, eds. Cruft et al. (Oxford University Press 2011) pp. 103-122.

24 See Lacey 2001 pp. 249-276, at 249; Lacey, Space, Time and Function: Intersecting Principles of Responsibility Across the Terrain of Criminal Justice, 1(2) Criminal Law and Philosophy (2007) pp. 233-250. For an explanation of the relationship between these two parts of her account, see Lacey, In Search of Criminal Responsibility ch. 1.

$25 \quad$ Ibid p. 235.

26 See Lacey, The Resurgence of Character: Responsibility in the Context of Criminalization in Philosophical Foundations of Criminal Law, eds. Duff and Green (Oxford University Press 2011) pp. 151-178, at 153-155; see also Lacey 2007 and Lacey 2016 ch. 1.

$27 \quad$ See Lacey 2016 ch. 2.

$28 \quad$ Lacey 2001 pp. 249-276, at 250, 268. 
demonstrating the changing coordination and legitimation requirements of the criminal law, and the influence of social, political and economic dynamics on criminal responsibility practices. ${ }^{29}$ Character-based responsibility ascription practices center on how conduct reflects back on the individual as an individual, and it is this reflection that is central to determining criminal responsibility. Counter-terrorism offences, which are mushrooming in many common law jurisdictions, are prominent examples of the renewed relevance of character to criminal responsibility (although, as Lacey notes, such offences also implicate risk as a basis for responsibility attribution).$^{30}$ Counter-terrorism offences may involve considerations of an individual's motives for conduct (something which is traditionally eschewed in criminal law in favour of intention), revealing that what is being evaluated is disposition or attitude, rather than intention as such. ${ }^{31}$ As Lacey argues, character-like responsibility produces a distinct formulation of the adjudication question: did the defendant's conduct 'express a settled disposition of hostility or indifference to the relevant norm of criminal law, or at least acceptance of such a disposition?.32

Negative ascriptions of responsibility (non-responsibility) are generally regarded as being based on capacity. The preeminent instance of non-responsibility - insanity - is almost always assumed - by lawyers, judges and criminal responsibility scholars alike - to be a clear-cut case of capacity-based non-responsibility. This reflects a largely unquestioned belief that the terrain of mental incapacity in criminal law should constitute 'the most fully developed aspect of the 'inner' or 'psychological' model of criminal responsibility. ${ }^{33}$ On the level of the positive law, the M'Naghten test for insanity is shot through with language of (in)capacity - in particular in the requirements that an individual must have a 'defect of reason' resulting from a 'disease of the mind. ${ }^{34}$ In case law on the insanity defence, it becomes apparent that M'Naghten insanity correlates with 'major mental disorders', or 'any mental disorder which has manifested itself in violence and which is prone to recur ${ }^{35}$ - clearly and strongly connecting the defence with impairment and disability. The notion of incapacity also suffuses scholarly analysis of insanity as non-responsibility. As Duff argues, the insanity plea operates to exempt those individuals who are not properly thought of as agents because they are not able to exercise a genuine choice in acting,

$29 \quad$ See Lacey 2007.

$30 \quad$ See Lacey 2016 pp. 147-148. See also Lacey 2016.

$31 \quad$ See e.g. Lacey 2011 pp. 151-178, at 169-174. These types of offences are dependent on the development of particular technologies, and mass data, which generate population-scale rather than individual and individualised knowledge about defendants. On anti-terrorism offences generally, Tadros, Crimes and Security, 71(6) The Modern Law Review (2008) pp. 940-970.

$32 \quad$ See Lacey 2007 pp. 233-250, at 239.

33 See Lacey 2016.

$34 \quad$ M'Naghten's Case.

35 Bratty $v$ Attorney-General for Northern Ireland (Lord Denning). 
or because they lack certain minimum capacities. ${ }^{36}$ Similarly, in Eric Colvin's words, 'the insanity defence rules identify special mental conditions under which persons cannot be expected to ensure that their conduct conforms to the requirements of law. ${ }^{37}$ And, again, according to John Gardner, while other defences are about the defendant's fitness for his or her role, defences such as insanity (and infancy) are straightforwardly about capacity. ${ }^{38}$

Despite the prominence of the language of incapacity, however, ascriptions of non-responsibility via insanity bear a strong imprint of character. I suggest that the ascription of non-responsibility via insanity is character-like. I have developed an argument to this effect in full elsewhere. ${ }^{39}$ Based on a systematic study of doctrines and practices of mental incapacity in criminal law (a category which, on my analysis encompasses exemption and exculpation on the basis of mental incapacity but extends beyond it, to include procedural doctrines like unfitness to plead), I developed a synthesised analysis of the terrain of mental incapacity in criminal law. Looking across this terrain, I suggested that the construction of 'madness' at the point of intersection with crime shares features with character-based conceptions of responsibility: 'madness' is constructed as both dispositional and able to be 'read' off an individual's conduct by different participants in the criminal justice process. My analysis of mental incapacity in criminal law revealed the subsisting significance of older ideas about the means by which certain types of human behaviour are evaluated, and the confidence with which evaluative judgments are made, in the operation of legal doctrines and practices. In relation to ascriptions of non-responsibility via the insanity defence, this reflects the particular ways of being and knowing that inform exemption practices (and colour exculpation and other allied criminal law practices based on mental incapacity).

It is useful to look closely at the insanity defence to illustrate this point. My point about the basis of ascriptions of non-responsibility via insanity may be explicated by reference to the sine qua non of the defence - mental disorder or disease. I suggest that the disease requirement of the insanity defence reveals the character-like basis of exemption via insanity. Disease is at the heart of the insanity defence. ${ }^{40}$ As mentioned above, the M'Naghten Rules stipulate that exemption via the insanity defence requires that the

36 See Duff, Choice, Character and Criminal Liability, 12 Law and Philosophy (1993) pp. 345-383, at 351-352, 356-57.

37 Colvin, Exculpatory Defences in Criminal Law, 10 Oxford Journal of Legal Studies (1990) pp. 381-407, at 392.

38 See Gardner, The Gist of Excuses, 2(1) Buffalo Criminal Law Review (1997) pp. 575-598, at 589.

39 See Loughnan 2012, ch. 3.

40 As a matter of the historical development of the law, the difference encoded by exculpatory insanity was gradually specified and medicalised to coalesce on disease: see Loughnan 2012, ch. 5. 
defendant suffer from a disease, and specifically, a 'disease of the mind. ${ }^{41}$ Disease has a dispositional quality that dovetails with the holistic assessment of responsibility entailed in character-like conceptions of criminal responsibility. Reflecting its origins in the realm of sciences of the body, the concept of a disease is something that has a global (or potentially global) impact on an individual, stretching out in time and space. ${ }^{42}$ In part because of the ontological features of disease - as pathology affecting a qualitative change on an individual - and in part as a result of the role played by expert medical evidence (which I discuss in the next section), the insanity defence is sometimes said to involve determination of the defendant's status rather than his or her capacity. As scholars like Michael Moore argue, insanity is properly understood as a 'status excuse', in that exemption depends on the 'accused's general status [as a non-rational person]', not 'the state of his mind at the time he acted'.3 As this suggests, in broad contrast with the paradigm case of (positive) ascriptions of responsibility, as an ascription of non-responsibility, insanity involves character-like bases for exemption.

Criminal responsibility scholars have not fully appreciated the significance of the disease requirement for ascriptions of non-responsibility. The disease requirement of the insanity defence, together with the requirement that the defendant also suffer from a 'defect of reason', ${ }^{44}$ is sometimes assumed to relate only to the (limited) scope, rather than the basis, of insanity. For some scholars, this feature of insanity reduces to a demand that any claim to exemption be proved or supported, that is, in effect to the suggestion that the disease requirement has mere evidentiary significance. ${ }^{45}$ As Mark Kelman writes, the role of 'hard science' in the insanity defence has meant that disease is 'more concrete, more

41 In addition to being of a certain kind (a 'disease of the mind'), the relevant disease must exist for sufficient duration (or to a certain intensity) to be able to be proved via (expert medical) evidence, even if it only affects the defendant momentarily (or episodically): see R $\mathrm{v}$ Kemp [1957] 1 QB 399; R v Sullivan [1984] 1 AC 156.

42 There is an enormous philosophical literature on the notion of disease: see e.g. Fulford, The Concept of Disease, in Psychiatric Ethics (2 ${ }^{\text {nd }}$ ed.) eds. Bloch and Chodoff (Oxford University Press 1991) pp. 77-99; Margolis, The Concept of Disease, 1(3) The Journal of Medicine and Philosophy (1976) pp. 238-255.

43 Moore, Causation and the Excuses, 73 California Law Review (1985) pp. 1091-1149, at 1098. For Moore, the 'language of mistake' adopted in M'Naghten has prompted a scholarly misunderstanding of insanity as a 'true excuse', one that focuses on particular actions at the time of the offence (ibid., pp. 1138, 1097).

44 This requirement of M'Naghten insanity limits the defence to individuals with cognitive defects, excluding those with disorders of emotion or volition (control or impulse): see $R v$ Kemp.

45 See e.g. Duff 2007 p. 286. For Duff, someone with a 'serious, all-embracing disorder or deficiency' is the 'clearest' example of a person 'incapable of functioning as a rational agent' (ibid.). See also Duff, Incapacity and Insanity: Do we need the Insanity Defence? in Mental Condition Defences and the Criminal Justice System, eds. Livings et al. (Cambridge Scholars Publishing, 2015) pp.159-177. 
thing-like' than other explanations for deviance. ${ }^{46}$ Other scholars regard this feature of the defence as a contingent product of the orientation of the defence around a particular cause of disability - an instance of what Paul Robinson calls a 'disability organised system of excuses. ${ }^{47}$ These analyses fail to grasp the deep significance of disease for non-responsibility on the basis of insanity: disease is not just evidence that there are grounds for an exemption in a particular case, or one of a broad set of excuses pertaining to either the defendant or his or her circumstances. Rather, its significance is that it points to the basis on which individuals are exempt via insanity - the disease requirement reveals that the basis of the ascription of non-responsibility via insanity lies in character, rather than capacity.

\section{Evidence and Proof of Responsibility and Non-Responsibility}

The second dimension of my analysis of responsibility and non-responsibility practices concerns evidence and proof. Preoccupation with the 'nature' of responsibility has meant that rules of evidence and proof governing responsibility and non-responsibility have been almost wholly marginalised in the scholarship on criminal responsibility. In recent years, however, there has been a growing recognition of the significance of these rules for the operation of criminal law principles such as criminal responsibility. ${ }^{48}$ When the rules of evidence and the burdens of proof attending responsibility and non-responsibility practices are compared, three main points of difference between these sets of practices become apparent, indicating that non-responsibility has a distinctive evidentiary and procedural frame in criminal law.

The first point of difference between evidence and proof of responsibility and non-responsibility is the existence of the presumption of responsibility: individual responsibility is assumed as well as required in criminal law, and, because responsibility is assumed, non-responsibility must be proved. Sometimes dismissed as a by-product of the need for some division of labour between prosecution and defence in the courtroom, the presumption of responsibility structures proof practices. ${ }^{49}$ Responsibility has a status quo character - unless the issue of the defendant's non-responsibility is raised at trial, his

46 Kelman, Interpretive Construction in the Substantive Criminal Law, 33 Stanford Law Review (1980-1981) pp. 591-673, at 648.

$47 \quad$ See Robinson 1997 p. 92.

$48 \quad$ See Duff et al. 2004, 2006 and 2007.

49 Presumptions are generally thought to be rules of law (rather than rules of evidence) (see Ho, A Philosophy of Evidence Law (Oxford University Press 2008) p. 97), but a presumption indicates that there are good grounds for believing a particular claim (although these grounds are somewhat incomplete): see Hall, Presuming, 11 The Philosophical Quarterly (1961) pp. 1021. 
or her responsibility will not be addressed as a matter of course. In the criminal law of England and Wales, this is expressed in the 'presumption of sanity. ${ }^{50}$ When a question is raised about an individual's criminal responsibility, as a matter of practice, the question for the court is whether he or she is non-responsible - not whether he or she is responsible. Thus, while it might be a convenient scholarly shorthand to ask if an individual is responsible ('who is responsible under criminal law?'), the question being asked is 'is this individual non-responsible?', and these questions differ from each other. The form the responsibility question takes reveals the assumption of individual responsibility, exposing the way in which the dice are loaded in favour of criminal responsibility.

The significance of the presumption of responsibility lies in its effects: the presumption of responsibility means that responsibility is unexceptional and non-responsibility is exceptional. It is in the presumption of responsibility (as the 'presumption of sanity') that the abstract reasoning individual of criminal legal theory takes form. As a number of scholars suggest, this abstract, reasoning individual has come to stand at the centre of criminal law principles and processes such as the criminal trial. In Alan Norrie's words, this reasoning individual has become a 'powerful mechanism of ideological legitimation' for the criminal law. ${ }^{51}$ In addition to being autonomous and rational, the subject of the criminal law is 'always accountable'. ${ }^{22}$ This must be seen to be a politically charged as well as contingent situation. As Lindsay Farmer argues, it is in the modern period that individual responsibility has come to be regarded as central to the conceptual order and the self-understanding of the criminal law. ${ }^{53}$ This is expressed through the idea that responsibility can act as a constraint on criminalisation via mens rea. However, Farmer argues that criminal responsibility was not in fact foundational to the modern law because of an intrinsic connection between wrongdoing and fault: the fact that it is thought to be so reflects the way individual responsibility is part of the modality of law, the way civil order is secured..$^{54}$ This modality or civil order rests on the generalisability of the juridical person - a person who can self-regulate and self-reflect, appreciate the importance of general norms of conduct for self and others, and develop his or her interests and identity over time - as the modern subject. ${ }^{55}$

The second point of difference between evidence and proof of responsibility and non-responsibility relates to the kind of relationship that exists between an individual

50 M'Naghten's Case.

51 See Norrie 2001 p.176. This is the 'juridical subject', in Norrie's words: see ibid. pp. 16-24 for discussion.

52 Rabin, Identity, Crime and Legal Responsibility in Eighteenth Century England (Palgrave Macmillan 2004) p. 110.

$53 \quad$ See Farmer 2016 ch. 6.

$54 \quad$ Ibid p. 165.

$55 \quad$ Ibid p. 168. 
and the explanation he or she has for engaging in criminal conduct. This kind of relationship differs for responsibility practices compared with non-responsibility practices: in relation to their explanations for conduct, defendants denying responsibility are positioned differently to those defendants not denying responsibility. This point can be grasped by reference to the legal-philosophical practice of organising defences along normative lines, into justifications (such as self defence) and excuses (such as duress), on the one hand, and denials of responsibility, on the other hand. ${ }^{56}$ Justifications and excuses constitute arguments that go to liability, while denials of responsibility go to responsibility. As Jeremy Horder argues, the 'moral relationship' between the defendant and the reasons he or she provides for criminal conduct differ between these cases. ${ }^{57}$ Horder develops a schema of defences categorised according to reasons for conduct, or explanations for engaging in wrongdoing. ${ }^{58} \mathrm{~A}$ defendant raising a justification or excuse is constructed as 'morally active': it is he or she who makes the defence. By contrast, a defendant making a denial of responsibility (a plea for an exemption) is constructed as 'morally passive': such a denial is not genuinely made by the defendant, but granted or awarded to him or her. ${ }^{59}$ As this indicates, non-responsibility practices position the defendant differently vis-à-vis his or her reasons for conduct - as passive as opposed to active - when compared with responsibility practices.

This connects with the third point of difference between evidence and proof of responsibility and non-responsibility, which concerns the types of knowledge that are brought to bear in assessing responsibility (that is, determining if an individual is non-responsible). Flowing both from its status quo character, and reflecting its centrality to criminal law evaluation and adjudication practices in general, responsibility is treated as generally 'knowable'. This means that it is the subject of general or common knowledge - lay people are competent to identify and evaluate it, and there is no need for additional informational resources to be enlisted in the process of determining (that is, assuming) responsibility. By contrast, reflecting (and reinforcing) its exceptional nature, non-responsibility requires expert knowledge. This expert knowledge, adduced at trial in the form of expert evidence, buttresses claims to exemption. The rationale for relying on expert evidence to assess non-responsibility is that it addresses matters lying beyond the competence of

56 This classificatory schema is a feature of several legal-philosophical analyses of criminal law: see e.g. Husak, The serial view of criminal law defenses, 3(3) Criminal Law Forum (1992) pp. 369400.

57 See Horder, Excusing Crime (Oxford University Press 2004) pp. 103-108.

58 Horder distinguishes between 'excusatory claims', 'diminished capacity claims' (by which he refers to something other than the extant partial defence of diminished responsibility), and 'denials of responsibility', arguing that these correspond to reasons with respect to which defendants are morally active, mixed reasons for conduct where defendants are both morally active and morally passive, and reasons for conduct with respect to which the defendant is morally passive, respectively: see ibid pp. 103-108.

$59 \quad$ See ibid pp. 103-08; see also Duff 2007 pp. 286-287. 
ordinary people (in the form of the jury) to evaluate. In the language adopted by Duff as part of his broader argument about responsibility as 'answerability', denials of responsibility (or 'agent exemptions') implicate someone other than the defendant: it falls to a 'third party' - not the defendant him or herself - to make the case for an exemption. ${ }^{60}$

Two aspects of the distinctive evidentiary and procedural framework of M'Naghten insanity illustrate this part of my analysis. The first aspect relevant here is the burden of proof. Uniquely in the common law of crime, the M'Naghten Rules place a substantive or legal burden on the defendant to prove insanity (the reverse burden of proof). This means that, unless the prosecution raises insanity because the defendant has put his or her mental state in issue (by raising the defence of diminished responsibility, for instance), the defence must prove the defendant's insanity to the balance of probabilities standard. ${ }^{61}$ The defence must prove non-responsibility, or, as the House of Lords stated in Woolmington, in insanity, 'it is incumbent upon the accused to prove his innocence. ${ }^{62}$ The explanation for the reverse burden of proof in insanity is complex and multi-layered, ${ }^{63}$ but the point here can be stated simply: non-responsibility on the basis of insanity is so exceptional that even the presumption of innocence - which has come to be known as the 'golden thread' of the common law of crime ${ }^{64}$ - does not apply to it. As an aspect of the evidentiary and procedural frame of insanity, the reverse burden of proof encodes the exceptionality of non-responsibility.

The second aspect of the evidentiary and procedural framework of insanity which is relevant here is the rule mandating expert evidence in support of the plea of insanity. As mentioned above, the M'Naghten Rules stipulate that the insanity defence must be left to the jury, ${ }^{65}$ but in recent decades, in England and Wales, statutory provisions have been introduced that require expert evidence to support any insanity plea. The Criminal Procedure (Insanity and Unfitness to Plead) Act 1991 introduced a requirement that no jury is entitled to find insanity without evidence from two or more registered medical

See ibid pp. 286-287; see also Baron, Excuses Excuses, 1(1) Criminal Law and Philosophy (2007) pp. 21-39.

${ }^{61} \quad R v$ Soderman (1935) AC 462; $R v$ Carr-Briant [1943] KB 607. If the defendant raises diminished responsibility, the prosecution is entitled to raise evidence tending to prove insanity: see Criminal Procedure (Insanity) Act 1964 (England and Wales), s 6.

$62 \quad$ Woolmington $v$ DPP [1935] All ER 1, p. 8.

63 George Fletcher argues that the reverse burden is a reflection of the criminal law's debt to 'private litigation', the civil (as opposed to criminal) law): see Fletcher, Two Kinds of Legal Rules: A Comparative Study of Burden-of-Persuasion Practices in Criminal Cases, 77 Yale Law Journal (1968) pp. 880-935, at 917; see also Loughnan 2012 pp. 163-165.

${ }^{64}$ The idea of the presumption of innocence as the 'golden thread' running through the criminal law dates from Woolmington $v$ DPP.

${ }_{65} \quad$ M'Naghten's Case; $R$ v Matheson p. 480. 
practitioners. ${ }^{66}$ As I have suggested elsewhere, by the time of the passage of the 1991 Act, expert evidence was essential to the legitimacy of the insanity plea, and the particular knowledge mix governing evaluations and adjudications of insanity - lay and expert had become a familiar feature of the criminal law on mental incapacity. ${ }^{67}$ For my purposes here, the relevant point is that this rule mandates that others make a case on behalf of the insane defendant: by contrast with excuses (which do not deny responsibility), where the defendant answers for him or herself, 'in the first person', as an agent, ${ }^{68}$ a 'third party' is necessarily involved in responding to the criminal charge. This rule about expert evidence for insanity exemplifies one of the differences between responsibility and non-responsibility practices in the criminal law.

\section{The Temporal Logics of Responsibility and Non-Responsibility}

Criminal law rests on particular relations between time, space, individuals and objects: that is, criminal law doctrines and practices encode particular temporal and spatial logics. Temporal and spatial logics are central to the enforcement of proscribed conduct and the definitions of crime (although they have been thought of as part of procedural rather than substantive law). ${ }^{69}$ According to Mark Kelman, who first introduced the 'time-framing' construct into criminal law scholarship, 'we neither frame time the same way in all criminal law settings nor do we explain why we use one time frame or another.70 As I discuss in this section, criminal responsibility and non-responsibility practices differ in their respective temporal logics: while ascriptions of criminal responsibility rely on a 'snapshot' timeframe, non-responsibility depends on an extended, or 'long exposure', timeframe.

Positive ascriptions of criminal responsibility rest on a 'snapshot' view of the relevant time. This is generally the moment of the coincidence of the actus reus of the alleged offence and the mens rea required by the offence. ${ }^{71}$ It is because of the 'snapshot' time-

66 Criminal Procedure (Insanity and Unfitness to Plead) Act 1991 (England and Wales) s1(1). Section $1(1)$ of the Act requires 'written or oral evidence of two or more registered medical practitioners at least one of whom is duly certified' before the jury may deliver a special verdict.

67 On the ongoing role of lay knowledge of mental incapacity alongside expert knowledge, see Loughnan, 2012, ch. 6 .

68 See Duff 2007 pp. 286-287.

69 See Farmer, Time and Space in Criminal Law, 13 New Criminal Law Review (2010) pp. 333-356.

70 See Kelman 1980-1981 pp. 591-673, at 592-593. Kelman suggests that rhetorical legal argument depends on 'interpretive construction' - a prior and implicit framing or characterisation of facts in issue. For Kelman, this process of framing in criminal law is ideological in that it reflects political considerations. See Farmer 2010, for a critical discussion of Kelman's analysis.

71 Kelman 1980-1981 pp. 591-673 at 633; see also Williams Textbook of Criminal Law (Stevens 1978). 
frame that motive or purpose of criminal conduct is disregarded (at least ostensibly), in favour of more technical and ostensibly neutral non-evaluative mental states such as intention. ${ }^{72}$ This 'snapshot' timeframe also extends to those defences that deny liability but not responsibility (justifications and excuses). As John Gardner writes, excuses and justifications are 'putative rational explanations' of a wrong or a mistake, and the relevant timeframe is the time at which the wrong or mistake was completed. ${ }^{73}$ Put another way, a defendant's justifying or excusing reasons, giving rise to claims for self-defence or duress, for example, are closed at the completion of the offence. ${ }^{74}$ While adherence to this 'snapshot' view is sometimes honoured in the breach (as in the doctrine of a continuing act), it remains a cardinal (limiting) principle of criminal law. In Kelman's words, this narrow time framing buttresses 'the traditionally asserted intentionalism' of the criminal justice system, the foundation of which is the principle that individual conduct is the result of free choice. ${ }^{75}$

By contrast, negative ascriptions of responsibility (i.e. non-responsibility practices) operate with a broader or 'long exposure' timeframe. The longer timeframe relates to those cases in which responsibility is in question ('is he or she non-responsible?'), not the cases in which it is assumed. As Gardner writes in relation to what he calls 'basic responsibility', denials of responsibility are not subject to 'the same freeze-frame restriction' that applies to positive ascriptions of responsibility. ${ }^{76}$ Rather, non-responsibility has what Gardner labels a diachronic or cross-temporal aspect. By this, he means that 'in respect of any one action in relation to which one's responsibility is in question, the question of whether one is responsible straddles the gap between the time at which the action was performed, and the time at which the question itself arises.77 In a similar vein to Gardner, and, in relation to non-responsibility, Victor Tadros suggests that, if the accused has suffered from something like a brain injury, that means that the identity of that agent qua agent cannot be determined simply at the point in time at which she acts - a longer timeframe is required to determine responsibility for conduct. ${ }^{78}$ The 'long exposure' timeframe dovetails with the distinctive basis of ascriptions of non-responsibility, discussed above: charac-

See Duff, Principle and Contradiction in the Criminal Law: Motives and Criminal Liability in Philosophy and the Criminal Law: Principles and Critique,, ed. Duff (Cambridge University Press 1998) pp. 156-204; and Horder, On the Irrelevance of Motive in Criminal Law in Oxford Essays on Jurisprudence Fourth Series, ed. Horder (Oxford University Press 2000) pp.173-191.

73 See Gardner 2003 pp. 157-171, at 157, 161.

74 See for discussion Horder 2000 pp. 173-191.

75 See Kelman 1980-1981 pp. 591-673, at 591, 600.

$76 \quad$ See Gardner 2003 pp. 157-171, at 157, 161.

$77 \quad$ Ibid pp. 157-171, at 157, 162.

78 See Tadros 2005 p. 141. 
ter-like bases for criminal responsibility situate attribution in a broader time frame than that which is implied by a capacity conceptualisation of responsibility. ${ }^{79}$

The way in which the 'long exposure' timeframe operates in non-responsibility is apparent in the insanity defence. As mentioned above, under the M'Naghten Rules, insanity exempts because either an individual is unable to understand the nature and quality of his or her act, or because he or she cannot appreciate that it was wrong. ${ }^{80}$ As several commentators argue, knowledge of the wrongness of an act is not an application of the ordinary rules of mens rea ${ }^{81} \mathrm{~A}$ defendant may have the mens rea for an offence, and yet, as a result of a 'defect of reason' resulting from a 'disease of the mind', he or she may not know that the act was wrong, meaning that he or she still falls within the bounds of the insanity defence. As a result, the insanity defence actually operates in one or other of two ways: it either negates an element of the offence (mens rea) or it exempts the defendant although he or she performed the actus reus with the requisite mens rea. ${ }^{82}$ And, if the latter, it functions in quite a distinctive way - over an extended time frame - reflecting the 'long-exposure' time-framing of non-responsibility practices in criminal law. Exculpation via M'Naghten insanity can be understood to impact on an individual in a way that resists the actus reus/mens rea dyad, invoking an idea of a condition stretched out in time - beyond the narrow slice in time corresponding with the commission of the actus reus. In Kelman's terms, this reflects the triumph of 'determinism' in criminal defences such as insanity - the idea that conduct is causally connected to prior events - over the 'intentionalism' dominant in other parts of the criminal law. ${ }^{83}$

Diminished responsibility serves as a useful further illustration of this point. In England and Wales, as in some other common law jurisdictions, diminished responsibility is a partial defence, which is available to murder only, and, where it is successful, it reduces murder to manslaughter. ${ }^{84}$ Although typically labelled a defence, diminished responsibility combines 'excusatory and denial-of-responsibility elements', and thus blurs the boundary between excuses and exemptions. ${ }^{85}$ That is, as with other parts of the criminal law that concern mental incapacity, there are connections between diminished responsibility and the central case of exemption, insanity. One such point of connection relates to time-framing. As a result of the recent Coroners and Justice Act 2009 (England

$79 \quad$ See Lacey 2007 pp. 233-250, at 233, 239.

80 See M'Naghten's Case.

81 See e.g. Smith, Insanity - Available as a Defence in Summary Trials, 129 Criminal Law Review (1997) pp. 129-133, at 133; Ward, Magistrates, Insanity and the Common Law, Criminal Law Review 796 (1997) pp. 796-804, at 802.

$82 \quad$ See e.g. Colvin 1990 pp. 381-407, at 394; Robinson 1997 p. 86.

83 Kelman 1980-1981 pp. 591-673 at 647-649. Kelman puts the defences of duress and provocation in this same category.

84 See Homicide Act 1957, s 2, as amended by Coroners and Justice Act 2009, s 52.

$85 \quad$ See Horder 2004 pp. 107-108. 
and Wales), the defence of diminished responsibility is available where a killing is caused or explained by an 'abnormality of mental functioning', arising from a 'recognised medical condition', which has 'substantially impaired' the defendant's 'ability' to understand the nature of his or her conduct, form a rational judgment or exercise self-control, and the 'abnormality provides an explanation for the defendant's act in doing or being a party to the killing. ${ }^{86}$ As this language suggests, while, formally, it is the actor's state at the moment of the killing that is at issue, the statutory references to 'ability' and 'abnormality' invoke a more status-like condition, one that is not reducible to a mere moment in time and space. The extended timeframe employed by the criminal law has an echo in the timeframe embedded in the types of expert knowledge enlisted to support claims of non-responsibility (discussed above). ${ }^{87}$

\section{Effects of Ascriptions of Responsibility and Non-Responsibility}

The final dimension of my analysis of responsibility practices concerns the effects of ascriptions of criminal responsibility and non-responsibility. By effects, I refer to what is made possible through these criminal responsibility practices. When the effects of responsibility and non-responsibility practices are examined, it becomes clear that, with liability achieving a moral fine-tuning of individual responsibility, positive ascriptions of responsibility are differentiated, while, on the other hand, ascriptions of non-responsibility are not differentiated, and leave blame or moral fault unapportioned or free floating.

The moral fine-tuning of individual responsibility via liability separates out what are, in effect, degrees or, more accurately, types of responsibility, meaning that positive ascriptions of criminal responsibility are differentiated. Responsibility and liability are distinct, ${ }^{88}$ but, in practice, they are difficult to fully or sharply separate - as Norrie argues, the 'architectonic of offence (mens rea plus actus reus) and defence' is a way of 'doing' criminal responsibility' ${ }^{89}$ Thus, while, in its positive form, criminal responsibility appears as if it were neatly demarcated from blameworthiness or culpability, liability and (positive

86 Coroners and Justice Act 2009, s 52, amending Homicide Act 1957, s 2.

87 I suggest that this extended timeframe is structurally embedded in the expert medical (psychiatric and psychological) knowledges enlisted in adjudications of criminal non-responsibility: see further Loughnan 2012 ch. 6.

88 As a conceptual matter, responsibility is a pre-condition of liability: for discussion, see Duff 2007 pp. 19-23. 
ascriptions of) responsibility are connected..$^{90}$ There are two aspects to this point, one concerning the elements of criminal offences, and the other concerning defences. First, differentiation of positive ascriptions of criminal responsibility is achieved by the different types of mens rea or fault - intention, recklessness, knowledge and negligence - that apply to different criminal offences. Different types of mens rea are generally considered to exist in a hierarchy of levels of culpability (although, according to critical scholars, an imperfect one), with intention at the top, permitting a grading of the blameworthiness of the offender and assessment of the relative seriousness of the offence. ${ }^{91}$ Even acknowledging that factors other than mens rea work to distinguish particular offenders and offences from other offenders and other offences (the grading of offences is also realised by the degree of harm the defendant causes, for instance, assault occasioning actual bodily harm as opposed to assault occasioning grievous bodily harm), ${ }^{92}$ and recalling that aggravating and mitigating factors will vary the punishment that follows a conviction for a criminal offence, ${ }^{93}$ it is possible to see that moral grading via mens rea achieves a kind of variegation of positive ascriptions of criminal responsibility.

The second way in which (positive ascriptions of) responsibility are differentiated concerns those defences that an individual may raise to avoid criminal liability, but which do not throw criminal responsibility into question. The moral fine-tuning of positive ascriptions of criminal responsibility is further enhanced if one takes into account these defences. This point can be grasped by comparing those defences classed as justifications or excuses (that is, defence arguments that go to liability) and denials of responsibility, a

90 For critique of the assumption about this neat separation, see Norrie, Simulacra of Morality?: Beyond the Ideal/Actual Antinomies of Criminal Justice in Philosophy and the Criminal Law: Principle and Critique, ed. Duff (Cambridge University Press 1998) pp. 101-155. Norrie argues that it is not possible to bracket culpability off from responsibility, and that responsibility involves both being 'called to respond' (answerability) and being 'found responsible' (culpability) (ibid, pp. 113-114).

${ }_{91}$ See, e.g., Moore, Intention as a Marker of Moral Culpability and Legal Punishability in Philosophical Foundations of Criminal Law, eds. Duff and Green, (Oxford University Press 2011) pp. 179-205 at 184. See also Tadros 2005 ch. 8; Duff, Intention, Agency and Criminal Liability (Blackwell 1990). What precisely underpins such a hierarchy, and what parts are played by the different types of mens rea, has been the subject of significant critique: for critical discussion about intention and culpability, see Lacey, A Clear Concept of Intention? Elusive or Illusory?, 56(5) Modern Law Review (1993) pp. 621-642; Norrie, Oblique Intention and Legal Politics [1989] Criminal Law Review pp. 793-807. See also Horder, Intention in the Criminal Law - A Rejoinder, 58(5) Modern Law Review pp. 678-691.

92 For discussion, see Horder, Rethinking Non-Fatal Offences against the Person 14(3) Oxford Journal of Legal Studies (1994) pp. 335-351; see also Fletcher, Rethinking Criminal Law (Oxford University Press 2000) on the 'harmful consequences' pattern of criminality.

93 According to Peter Cane, the type and severity of criminal sanctions are expressions of 'judgments about degrees of responsibility': see Cane 2002 p. 34. 
distinction discussed above. ${ }^{94}$ Unlike denials of responsibility, like insanity, justifications and excuses constitute 'exculpatory answers for the commission of the offence for which responsibility has been proved. ${ }^{95}$ That is, raising a justification or excuse in response to a criminal charge is asserting responsibility. ${ }^{96}$ As Duff writes, 'to offer an excuse is to admit responsibility for an action' and to 'offer an exculpating answer. ${ }^{97}$ On this view, justifications and excuses are within the realm of criminal responsibility in its positive form, and represent a further adjustment of (positive) ascriptions of responsibility. While critical scholars have debated what exactly is achieved by this demarcation of justification and excuse, and also what is achieved by robustly maintaining the distinction between actus reus/mens rea and defences, ${ }^{98}$ for my purposes here, what is clear is that the realm of positive ascriptions of responsibility is differentiated, finessed by liability (mens rea and defences).

In comparison, ascriptions of non-responsibility are not so differentiated, meaning that the effects of ascriptions of non-responsibility are less variegated and more open-textured, with blame or moral fault left free-floating. This point can be grasped by reflecting on the characteristics of exemptions. There are two aspects to this point. First, at least formally, non-responsibility is an either/or construction. That is, an individual is either a subject of the criminal law or not, someone to whom the law speaks or not, a person within its reach or beyond it. This reflects the traditional idea that a defendant is either accountable for his or her act, or not accountable at all. Unlike positive ascriptions of responsibility, no degrees or types of non-responsibility are formally permitted. At least as a conceptual matter, it is not possible for someone to be somewhat or partially accountable. ${ }^{99}$ In Jerome Hall's words, 'legal adjudication and the inexorable logic of its method, implied in the issue whether a person does or does not fall within the reach of the prescriptions, require a determination that the defendant is responsible or that he is not responsible. There is no other alternative. ${ }^{100}$ This either/or, black-and-white aspect of non-responsibility does not permit shades of grey.

this normative schema, justifications and excuses exist in a hierarchy, where the former are more preferable than the latter: see Gardner 2003 pp. 157-171 at 161; see also Gardner 1997 pp. $575-598$ at 575.

$95 \quad$ See Duff 2007 p. 263. See also Horder 2004 p. 105; Kadish, Excusing Crime, 75(1) California Law Review (1987) pp. 257-289, at 262-263.

$96 \quad$ See Gardner 1997 pp. 575-598, at 588 (emphasis added).

$97 \quad$ See Duff 2007 p. 285.

98 See Norrie 2001; see also Norrie 1998 pp. 101-155.

$99 \quad$ Walker, Crime and Insanity in England, Vol 1 (Edinburgh University Press 1968) p.162. This has generated challenges in reconciling the partial defence of diminished responsibility with legal principle: see Loughnan 2012, ch. 9.

100 See Hall, Intoxication and Criminal Responsibility, 57(7) Harvard Law Journal (1944) pp. 10451084, at 1081. 
Second, because non-responsibility blocks liability, there is no (subsequent) grading of non-responsibility, and blame is left more free-floating. By contrast with proof of responsibility, which creates a presumption of liability, leaving it to the defendant to block the 'normal presumptive transition' from responsibility to liability, ${ }^{101}$ non-responsibility renders liability redundant. Absent liability, non-responsibility is not finely graded in the way of (positive) responsibility. Because the ascription of non-responsibility stops any enquiry into blame, in its negative form, non-responsibility, fault is unaccounted for or unapportioned. That is, it is not possible to make a judgment about an individual's culpability. In Duff's terms, someone who is 'so seriously disordered as to be non-responsible' falls 'outside the reach of reasons' and the 'judgment' of the criminal law. ${ }^{102}$ In this respect, exemption stands in contrast with justifications or excuses, like self-defence, for example, where fault is absent or eclipsed by the rightness of the defendant's act or his or her reasons for it. ${ }^{103}$ The effect of ascriptions of non-responsibility is that the criminal legal process has failed to conclude the responsibility question relating to the offence: a harmful act has been done, but the individual charged with it cannot be held responsible for it. I return to this point in relation to the implications of my analysis in the concluding section of this article.

Again, drawing on the law of insanity assists in illustrating this point about the effects of ascriptions of non-responsibility (exemptions). Here, the result of a successful insanity defence - the special verdict - is instructive. As mentioned above, in England and Wales, the special verdict provides that an individual is 'not guilty' because of insanity ('not guilty by reason of insanity'), giving both the verdict ('not guilty') and the factual basis for it ('insanity'). ${ }^{104}$ This formula seems to imply that the issue of blame has been addressed along with the issue of responsibility, that both moral and legal questions have been concluded. But the situation is not so neat, and we do not have to go too far to find other kinds of relationships between insanity and fault posited in the insanity defence. ${ }^{105}$ As recently as the post-war period, overt consideration of moral fault was

$101 \quad$ See Duff 2007 p. 22. See also Hart, Punishment and Responsibility (Clarendon Press 1968) pp. 212222 (where Hart distinguishes between 'role responsibility' and 'legal liability-responsibility').

102 See Duff 2007 p. 290.

103 See Fletcher, The Nature of Justification, in Action and Value in Criminal Law eds. Shute et al. (Clarendon Press, 1993), pp. 175-186.

104 M'Naghten's Case.

105 In England and Wales, for a period of time over the end of the 1800s and first half of the 1900s, the form of the special verdict was 'guilty but insane so as not to be responsible according to law for his actions'. In the Trial of Lunatics Act 1883, the special verdict was repackaged as 'guilty but insane' thus technically altering its form to a conviction from an acquittal. For discussion, see Moran, The Origin of Insanity as a Special Verdict: The Trial for Treason of James Hadfield, 19(3) Law and Society Review (1985) pp. 487-521 at 519. It is only since the passage of the Criminal Procedure (Insanity) Act 1964 that the form of the special verdict has been 'not guilty by reason of insanity': see Criminal Procedure (Insanity) Act 1964. 
considered compatible with the grant of the insanity defence. The proposal presented by the Royal Commission on Capital Punishment in its 1953 Report recommended that a jury considering the insanity defence should be directed to determine whether 'at the time of the act the accused was suffering from a disease of the mind (or mental deficiency) to such a degree that he ought not to be held responsible'. ${ }^{106}$ This reformulation of the test for insanity makes overt the moral-evaluative considerations entailed in granting the defence, even where a relevant mental disorder exists. As Roger Smith argues, this proposal rested on the belief that 'responsibility was essentially a subjective, ethical question, making the relationship between insanity and criminal responsibility inherently incapable of precise definition. ${ }^{107}$ As this formulation of the insanity defence indicates, moral fault was not considered extinguished by a particular mental condition - the moral question whether the condition ought to be exempt is identified as a separate matter, lingering within the realm of non-responsibility.

\section{Conclusion}

This article has offered an assessment of legal scholarly analysis of responsibility and non-responsibility in criminal law. I explicated current scholarship on criminal responsibility by reference to the kinds of questions that may be asked by responsibility scholars. As mentioned at the outset of the discussion, the question that has tacitly guided the dominant strain of criminal responsibility scholarship (informed by the legal-philosophical tradition) is something like 'who is responsible under criminal law?', or 'who should be responsible under criminal law'. This guiding question has followed from a scholarly preoccupation with the 'nature' of responsibility. The question 'who is responsible under criminal law?' produces a picture of responsibility and non-responsibility as different sides of the same coin, alternative outcomes of the same moral-evaluative enquiry of calling individuals to account for their criminal conduct. This reduces the relationship between responsibility and non-responsibility to one of, in effect, responsibility and a-responsibility.

Adopting a more critical approach to criminal responsibility - understood as a set of practices taking place in a particular criminal institutional context - generates a different responsibility question - 'in what ways are individuals held responsible in criminal law?'. Inspired by the critical scholarship on criminal responsibility practices that asks different responsibility questions, this article considered the question 'how do criminal responsibility and non-responsibility practices compare?'. A close examination of four

106 United Kingdom Royal Commission on Capital Punishment 1949-1953 Report (Cmd 8932, 1953) para. 333 (emphasis added).

107 Smith, Lawyers, Legislators and Theorists: Developments in English Criminal Jurisprudence 18001957 (Clarendon Press 1998), p. 327. 
dimensions of criminal responsibility and non-responsibility - ascriptions of responsibility and non-responsibility, attendant rules of evidence and procedure, the temporal logics of responsibility and non-responsibility, and what I called the effects of ascriptions of responsibility and non-responsibility - revealed meaningful differences between the two sets of practices. My analysis suggests that criminal responsibility and non-responsibility do not sit in a straightforward relationship with each other: non-responsibility is not a-responsibility, or simply not responsibility. By way of conclusion, I briefly mention two implications of my analysis.

One implication of my analysis relates to the political dimensions of non-responsibility practices in criminal law. Non-responsibility practices leave a kind of political remainder, which is obscured in accounts that regard responsibility and non-responsibility as alternative outcomes of the same moral-evaluative inquiry. As mentioned above, non-responsibility leaves moral fault free-floating. This free-floating moral fault means that the legal process has failed to conclude the responsibility questions relating to the offence. So, while we might argue that, in the current era, blameworthiness in criminal law is not supposed to be a 'hovering wickedness', but to attach to particular harmful acts, ${ }^{108}$ something like a 'hovering wickedness' haunts non-responsibility. When criminal responsibility practices are viewed in a broader context, a finding of non-responsibility can be seen to generate other responsibility questions. In relation to insanity, such questions may include is there someone else, perhaps a negligent medical professional, or something else, such as a care facility without adequate safeguards in place, who/which bears some moral responsibility for the act committed by the defendant?'. These individuals or institutions may be out of the criminal law frame, but within any moral-evaluative frame (and perhaps also within any civil law responsibility frame like tort). Such political remainders may also follow ascriptions of responsibility, ${ }^{109}$ but it seems to me that the political remainder is more prominent, and also more problematic, and in particular need of careful, scholarly attention, when it comes to non-responsibility.

A second implication of my analysis relates to the extant position of non-responsibility in the legal-philosophical criminal responsibility scholarly tradition. Reflecting the connections between legal-philosophical accounts of criminal responsibility and liberal political philosophy (both of which are concerned with individual autonomy, freedom and privacy, and with the duties owed by the individual to the polity ${ }^{110}$ ), the primary significance of a finding of non-responsibility in these accounts is normative - it marks

108

See Kelman 1980-1981 pp. 591-673 at 633.

Norrie argues that individual responsibility is always intermixed with social responsibility for wrong-doing meaning that this would apply as much to ascriptions of responsibility as to ascriptions of non-responsibility: see Norrie 1998 p. 117.

See e.g. Duff, Responsibility, Citizenship and Criminal Law in Philosophical Foundations of Criminal Law, eds. Duff and Green (Oxford University Press 2011) pp. 125-148. 
out a space where the moral-condemnatory power of the law runs out. As this suggests, non-responsibility represents a limit on the reach of the criminal law. As Eric Colvin writes regarding insanity, this defence applies to exceptional individuals, non- or less than full subjects of the criminal law, or improper targets of criminal sanctions, those for whom the 'general law of criminal culpability is unsuited'. ${ }^{11}$ Similarly, for Duff, an individual who is not responsible is someone who is an 'object' rather than a 'subject' of the criminal law. ${ }^{112}$ In these legal-philosophical accounts of criminal responsibility, non-responsibility is a kind of residual category, defined by the absence of conditions of responsibility. But on my analysis, non-responsibility looks different to responsibility, meaning it is not a space that may be fully grasped merely in opposition to responsibility. And this gives rise to an imperative to take non-responsibility practices seriously, and to appreciate their distinctive features, rather than subsume them beneath a general focus on criminal responsibility. This article is a contribution to that endeavour.

111 See Colvin, 1990 pp. 381-407, at 402.

112 See Duff 1986 p. 122; see also Tadros 2005 pp. 55-56. 